\title{
School Effects on Adolescent Substance Use: Prevention through Interactive and Social Learning Strategies
}

\author{
Eleni Stefanidi' ${ }^{1}$, George Tsitsas ${ }^{2}$ \\ ${ }^{1}$ Secondary Schools of Greece, Athens, Greece \\ ${ }^{2}$ Counseling Centre, Harokopio University, Kallithea, Greece \\ Email: elstefanidi@hotmail.com
}

Received 3 December 2014; accepted 1 April 2015; published 3 April 2015

Copyright (C) 2015 by authors and Scientific Research Publishing Inc.

This work is licensed under the Creative Commons Attribution International License (CC BY). http://creativecommons.org/licenses/by/4.0/

(c) (i) Open Access

\section{Abstract}

This study aimed to examine: a) the factors in Greek schools that are related to the school course of the adolescent drug abusers; b) the effectiveness of new interactive and social learning strategies in preventing drug use. Data were drawn from a face-to-face survey carried out on population of ex-drug abusers that were attending therapeutic programs of STROFI-KETHEA and in other places such as private with psychiatrists. The sample was 22 boys and 8 girls aged 16 to 21 years. All participants had a drug use experience and high rates of school drop out. The results suggest that factors related to the Greek school environment-meaning its culture, sense of community, education strategies-have negatively affected the school course of the participants. The poor school connectedness and dropping out effect negatively on young people's behavior and drug use problems. Prevention should be considered through a new approach of the education system.

\section{Keywords}

Adolescent Substance Use, School Drop out, Prevention, Learning Strategies

\section{Introduction}

Youth substance use and the resulting damage are recognized as significant global public health issues in society today (WHO, 1997; WHO, 1999; WHO, 2001). Adolescent use of tobacco, alcohol, cannabis and other drugs has risen over the last decade in many countries (EMCDDA, 2008; Hibell, Andersson, Bjarnason, Ahlström, Balakivera, Kokkevi, \& Morgan, 2004; Karam, Kypri, \& Salamoun, 2007; Parry, Myers, Morojele, Flisher, Bhana, Donson, \& Plüddemann, 2004; Cochrane, Chen, \& Conigrave, 2003; Simons-Morton, Farhat, ter Bogt, 
Hublet, Kuntsche, Nic Gabhainn, Godeau, \& Kokkevi, 2009), in spite of the increased information about the potentially serious health, social, and psychological consequences. Initiation of drug use in childhood and adolescence increases risks for a range of serious health and behavior problems, including accidental injury, depression, suicide, unprotected sex, teen pregnancies, violent crimes and antisocial behavior (Duncan, Strycker, \& Duncan, 1999; Miller, Naimi, Brewer, \& Jones, 2007; Melzer-Lange, 1998; Galaif, Sussman, Newcomb, \& Locke, 2007).

Adolescence is a phase of exposure to several risk behaviors, especially the experimental use of drugs. A number of studies have demonstrated that drug use often begin early (EMCDDA, 2008; Hibell, Andersson, Bjarnason, Ahlström, Balakivera, Kokkevi, \& Morgan, 2004; Yamaguchi \& Kandel, 1984; Kandel \& Logan, 1984). The age at which a young person first use drugs is predictive of later problems with these substances, with earlier use placing individuals at greater risk for later abuse (Hawkins, Catalano, \& Miller, 1992; Yu \& Williford, 1992). Furthermore, studies have demonstrated that marijuana, that is commonly used by adolescent, is important precursor to the use of "hard” drugs such as heroin or cocaine (Lynskey, Heath, \& Bucholz, 2003; Ferguson, Boden, \& Horwood, 2006).

A number of studies have identified that social interactions and environmental factors are important determinants of adolescent drug use. Psychological distress and depression mood followed by the present socioeconomic status influence on the probability of adolescents’ engaging in drug use (Stefanis \& Kokkeve, 1986; KETHEA, 2007). Antisocial behavior and peer-oriented lifestyle can affect adolescent drug initiation (Kokkevi, Arapaki, Richardson, Florescu, Kuzman, \& Stergar, 2007). Exposure and attachment to substance (such as cannabis)-using peers and parents and lower family socioeconomic status are also strongly predictive of increased risk for early initiation (Madarasová, Stewart, van Dijk, Orosová, Groothoff, \& Post, 2005). Substance use seems to be significant in violent communities, particularly for children (Cooley-Strickland, Quille, Griffin, Stuart, Bradshaw, \& Furr-Holden, 2009). Poor family practices to set clear limits and rules, monitor their adolescents' behaviors and provide a loving and supportive environment may affect their children's substance use (Kodjo \& Klein, 2002). Studies demonstrate that drug use increase across immigrant generations (Hamilton, Noh, \& Adlaf, 2009). Negative school and social connectedness can be at elevated risk of adolescent regular smoking, drinking, and using marijuana in later years (Bond, Butler, Thomas, Carlin, Glover, Bowes, \& Patton, 2007).

The rates of smoking and drinking among adolescents in Greek schools have remained at unacceptably high levels, despite the well-known adverse effects on health. Initial use of smoking often occurs at first grades of high school and more than one third of adolescent reports smoking one or more cigarettes (Apostolaki, 2001). Alcohol continues to be the most common substance of abuse among students in greek schools. Nearly $90 \%$ of high school students report having used one or more drinks at some time in their lives. Use of alcohol is associated with use of smoking (Apostolaki, 2001). Many studies indicate that early adolescence (13 - 15 years old) is a particularly risky period for initiation illicit drugs and boys appear to be at greater risk for drug abuse. The risk of drug initiation and use in students climbs steeply throughout adolescence and peaks higher rates at the age of 16 - 18 (Kokkevi, Nic Gabhainn, \& Spyropoulou, 2006; Andersson, Hibell, Beck, Choquet, Kokkevi, Fotiou, Molinaro, Nociar, Sieroslawski, \& Trapencieris, 2007).

Resent studies have examined the relationship between dropping out of high school and the use of substances. Initiation of alcohol, cannabis and other illicit drugs is positively related to dropping out of school (Townsend, Flisher, \& King, 2007). Increasing cannabis use in adolescence seems to be associated with increasing risks of poor school performance, lower grade point average and early school leaving without qualifications (Lynskey \& Hall, 2000). However, both outcomes, substance use and school drop out, are largely linked.

In Greece, primary education (elementary school) and secondary education (gymnasium and lykeium, i.e. junior and senior high school respectively) are part of the educational structure. The basic education lasts for nine years-the minimum qualification for an 'ordinary' job or place for a training scheme- and reaches until gymnasium. A significant percentage of pupils usually drop out before graduating. A survey of the drop-out problem established a drop-out rate of 6.98\% in gymnasium (Rousea \& Vretakou, 2006). Findings of a research among the population of ex-drug abusers that were attending therapeutic programs of KETHEA indicate that factors related to the function of school have negatively affected their school course. High pressure about educational matters and the school environment's denial to deal with the drug problem turn the adolescent towards school failure and in most cases towards school drop out (Koutrouvidis \& Koutras, 2007).

Many studies have focused on the development of school-based prevention programs for drugs that contribute 
to preventing drug use and mitigating the consequences of drug use. The school-based drug prevention programs are designed as skill-based programs-decision-making and social skills- and aim in deterring early-stage drug use (Faggiano, Vigna-Taglianti, Versino, Zambon, Borraccino, \& Lemma, 2008). However, recent research has promoted the interest in "whole-school" drug prevention interventions that go further than a classroom-based prevention program, and make changes to a school's overall organization and culture in order to promote young people's health, including in relation to substance use (Fletcher, Bonell, \& Hargreaves, 2008). The School-based education for drug abuse prevention should be defined as a set of total learning and social experiences to which students are exposed over their time at school that contribute to preventing drug use and mitigating the consequences of drug use.

School is a social and learning environment which provides the setting for successful education outcomes. The challenge for schools is to convey the importance of the school environment as a setting for successful educational outcomes to the school community. Schools values, beliefs and educational goals should be outlining in a mission statement, which motivates all members of a school community to work together. Strong bonds to school serve as a protective factor against antisocial behaviors and substance use (Bond, Butler, Thomas, Carlin, Glover, Bowes, \& Patton, 2007). The factors that affect children's bonding are the degree of opportunity for active involvement in classroom and in general school activities. Early interactive intervention through the elementary grades should lead children to positive learning and behavior outcomes over the long term.

The success of school-based education for drug abuse prevention should give an emphasis in learning outcomes, environmental factors and collaborative partnerships. The modern education strategies are based to social learning theories (Bertrand, 1994; Meyer, 1995; Vygotsky, 1997). Teaching and learning should be interactive and social-based. Teaching techniques such as discussions, decision-making, experiential and experimental learning, project methods, role-playing, organized in small groups of pupils, stimulate the active participation of all students. Teachers should be familiar with interactive classroom strategies and support the active participation of students to these strategies activities in groups, which encourages peer to peer communication and maximum participation. Teachers should be aware of the wide range of behaviors in adolescents, such as substance use, and understand of the life skills needed by adolescents to deal with the challenges of adolescent life. It is also important that school must be democratic, provide a clear mission statement and support dynamic relationships among community members.

The aim of this paper is to examine the factors in Greek schools that are related to the school course of the adolescent drug abusers and the effectiveness of new interactive and social learning strategies in preventing drug use. The data derive from ex-drug abusers students that were attending therapeutic programs and recovery school programs.

\section{Methodology}

\subsection{Participants' Profile}

Thirty adolescents and young members-students of the therapeutic program STROFI-KETHEA (8 female, 26.6 percent and 22 male, 73.4 percent) took part in this survey. Participants were not chosen at random but formed a "convenience sample" (Peers, 1996) selected through personal contact on the basis of availability. All the participant were ex drug users. At the time of the survey age ranged from 16 to 21 years $(\mathrm{M}=19.6 ; S D=1.4)$. About $27 \%$ of the sample was female $(n=8)$ and $73 \%$ were male $(n=22) ; 90 \%$ were Greek $(n=27)$ and the rest $10 \%$ were Albanian living in Greece $(\mathrm{n}=3)$.

\subsection{Procedures}

Trained interviewer asked questions about substance use after participants signed the informed consent approved by the ethics committee. The students meeting took place in the Commutative School of "Strofi". Having obtained the important cooperation and help of the School's editors and professors, the researcher presented the aim of the research along with the incentives for its completion. The form assured the confidentiality of the answers, and that those were used for research purposes only. Participation was voluntary, and subjects could withdraw at any time.Voluntary participations for completing the questionnaire were asked for and the classification of the recorded data was affirmed. It was, also, clarified to the students that for the first questionnaire, they should record their aspects about the prevailing school class environment during their last year of study in 
the Greek school and not in their current school, the Commutative School of "Strofi". For the second questionnaire they should mention their opinions concerning the preferable school operation mode.

The aforementioned sample characteristics, i.e. drug abuse history, variety of family characteristics, types of school failure, along with the fact that these youngsters together with their families have sought assistance in the particular programme and have regained contact with education through the Commutative School of "Strofi", render the research sample appropriate to demonstrate the students perceptions about the school they attended during their drug abuse, but also for the school they regard as an appropriate social institution for education and drug prevention.

\subsection{Instruments}

The selected research method was the recording of students' characteristics, such as: age, educational historic, family characteristics, etc. Also, the students completed two questionnaires (see on Appendix) related with school education. The first questionnaire was based on- "The school class's environment” questionnaire (Matsaggouras, 1987) that inquires the students' aspects on their class's way of function. The second questionnaire has been designed from the researcher of this study, according to current aspects and methods of student-focused learning and group-cooperative teaching. (Ausubel, Novak, \& Hanesian, 1978; Bertrand, 1994; Fontana, 1996; Gardner, 1993) and explores students’ ideas about the preferable type of school.

\section{Research Results}

\subsection{Social Profile of the Students and Their Families}

The majority of the sample's nationality is Greek (90\%), whereas a small percentage (10\%) of the students was born in Albania and lives in Greece. Most of the children lived in different suburbs of Athens (73\%) and the rest of them came from country cities (27\%) and were hosted in the Community's hostel, while attending the Special Treatment Program. Table 1 presents the participants' demographic characteristics.

As far as the parents' educational level is concerned, the highest percentages relate to senior/high school and upper education (65\%), whereas the percentages of (20\%) surpass the university ones (15\%). Regarding father's occupation, labor jobs such as, driver, builder, private employee, cleaner, predominate, while a $6,7 \%$, appears to be unemployed. In regards to mother's occupation, labour jobs such as, cleaner, housekeeper, hairdresser, prevail while the unemployment rate reaches a significant high of $26.6 \%$.

\subsection{School Failure and Interruption}

Although the sample students have an average of 19.6 years of age, only $13 \%$ holds a certificate of High School studies. The $77 \%$ of the students hold a certificate of Senior School studies and a small percentage of $10 \%$ holds only a certificate of Primary School studies. If the percentage of High School graduates is excluded along with the 8 out of 30 students that attended the High School of "Strofi", the rest of the students have deserted school. Most of them abandoned school from 1 up to 10 years before they decided to attend the Special Treatment programme.

The school desertion phenomenon appears to be quite often in High school, since high percentages of school interruption were detected in $1^{\text {st }}$ and $2^{\text {nd }}$ class of the High school $(59 \%)$. Also the children recorded relatively low grades with an average of 12.5 in the last school class they attended before their treatment.

The students' feelings of despair and disappointment about lessons, examinations, their tutors and their parents who displayed no care and understanding, were raging high (67\%).

Absence from the classes was very frequent. $87 \%$ of the sample's children indicated that they were absent from the lesson frequently/very frequently, that is from three to six times per week. The majority of them (97\%) claimed that they preferred to do other things such as using drugs, than going to school. Other reasons of absence, such as inability to sleep at night or get up in the morning (50\%), health problems (40\%), inability to do the homework and attend the lesson (37\%), lack of interest in the Greek school (30\%) and the fear of failure (27\%), were also recorded. The presence of these children in the classroom was indifferent, since they were not attending the lesson's process (67\%), they were not interested in the way the lesson was processing (63\%). Also, they were incapable of understanding due to drug abuse (27\%), while sometimes they were falling asleep during the lesson (10\%). 
Table 1. Participants' demographic information $(N=30)$.

\begin{tabular}{cc}
\hline Variable & $\%$ \\
Race/ethnicity & 90 \\
Greek & 10 \\
Albanian & 73 \\
Place of living & 27 \\
Athens & 20 \\
Country cities & 65 \\
Parents' educational level & 15 \\
Elementary school education & \\
Senior/high school and upper education & 93.3 \\
University & 6.7 \\
Father's occupation & 26.6 \\
Labor jobs & 73.4 \\
Unemployed & \\
Mother's occupation & \\
Labor jobs & \\
\hline
\end{tabular}

Answers on the question "which do you think is the reason that some children desert school before they take the Primary/Senior/High School studies certificate?” were particularly interesting. The children claimed that the main reasons for school interruption are the need for a job (35\%), disappointment from school (32\%), the notion that school is probably unnecessary for finding a job (20\%), as well as, drug abuse (13\%).

When asked whether they were going to take the Senior/High school studies certificate, $57 \%$ answered "absolutely yes" (this includes all students frequently attending the Commutative School of "Strofi"), 23\% answered "not sure", $3 \%$ "absolutely no", while the rest of them did not reply.

Regarding the school class environment, the sample's students reported that there was competition among the children concerning their progress and their grades. Most of the times, they didn't find the lesson appealing and their homework was rather difficult and more suitable for bright students. They also mentioned that most children in their last class were not feeling friends with each other, they were frequently fighting and did not find the class appealing to them.

\subsection{Type of School Preferred by Students}

Over $80 \%$ of the thirty sample students, rejected the current traditional teaching methods and the despotism of the school environment and indicated the student-focused and democratic school as the one which best responds to their needs and also to the needs of all students.

As far as the lesson delivery is concerned, instead of the monologue and the professor lecturing, the students showed preference towards mutual dialogue and the ability for everyone to express his opinion. They also considered significantly important for the class lesson to be interesting and to help them face their needs and problems. The ability to propose topics for discussion in the class and not just literally follow the school book curriculum, seems to be appealing to them.

Participating in group activities during the lesson, such as an experiment's preparation in biology or in physics, seemed very interesting to the children, in contrast with the theoretical class lesson. The majority of the students seem to be attracted by the participation in group activities, as students prefer to join and work in groups. Outdoor group activities, such as sports, students' newspaper and theatrical performance, are considered to be 
appealing activities, the same as visiting scientific and cultural places outside school.

Almost $80 \%$ of the sample voted for programmes such as "Work Project", in which students choose a topic, for example the use of alcohol, separate in groups, search information about it, visit relevant places and prepare a project which they present, supported by their professor. Programmes of "Environmental Education" were equally preferred.

In regards to the way school books are written, a significant $70 \%$ of the sample argued in favor of the "via-thematicity", which means that books describe concepts using practical and theoretical sciences. Moving on to class desks arrangement, $57 \%$ showed preference towards the " $\Pi$ " form, versus the parallel lines formation. Even though the parallel lines' arrangement is the most common in class, still the circlular layout gathered the higher rates of preference. Almost all students considered the use of electronic means during the lesson, as well as the lesson in school laboratories as absolutely necessary.

Around $97 \%$ of the students chose the democratic instead of the despotic professor and claimed that the professors' role must mainly focus in offering advice and support to students' problems and not just deliver the book's content and rate students with good or bad degrees. In regards to whether the professor should give emphasis to the sex characteristics of the individual, such as age and sex, 50\% answered in the affirmative and 50\% not. The students have probably misunderstood the specific question and didn't realize that it applied to the professor's interest about the individual features of each child and not to racist behaviors.

The students expressed their preference towards the existence of rules in school and their compliance with them, while at the same time feeling free, being creative and active. They believe that the professors together with the students should decide on the rules that set the lessons' delivery and they must all respect these rules. They believe in a democratic school environment and mutual respect between professors and students. They argue for freedom of opinion, respect to the otherness of each person and mutual communication.

Almost $80 \%$ of the students would like to have trustworthy relations with their professors both inside as well as outside the classroom. Questions related with students' infrigeration and the lack of interest for the lesson, were answered in ways that promote the effort that should be made from the professor to devote significant time to the children and make his lesson more interesting. Rigid punishments and inconsideration were condemned. A child who is under drug abuse should not be treated with punishment and school interruption, but in a way that provides solutions through a collaborative environment of professors, students and parents. The $57 \%$ of the students believe that the school needs to cultivate strong relations with the family and the society, whereas the opposite opinion is supported by $43 \%$ of the sample. Most probably this $43 \%$ denotes the fear and the insecurity that the students have about their family and the society as a whole.

Asked about the school where they would like to be students, the children wrote the following interesting answers: "new building”, "post-lesson activities", "non anachronistic ways of teaching”, "professors standing by the students", "to prepare the students appropriately for entering the society", "few children in the classroom", "free choice of lessons", "freedom of opinions", "professors help in weak students", "the professors not to consider themselves as omniscient”, “creative activities”, “democracy”, “understanding”, "respect”, "natural environment”, "team work”, “amusement”, "school free of drugs”.

\section{Discussion}

This research is an effort to study the behaviors and attitudes towards school of a sample of students, who were members of the Special Treatment Community "Strofi". The study also intended to correlate the ways that the school operates with the phenomena of school failure, school desertion and drug abuse. Students' perceptions concerning the sort of school which could have an effective educational role and also the ability to operate as a place of prevention against addictive substances were also studied.

Out of the population that participated in the current research, a large amount comes from Athens who live with members of their family such as their mother, brothers, grandfather, grandmother. The parents' educational level varies, however, senior and higher education prevails. A large number of the sampled children claimed that they were feeling desperate and without understanding from their parents too frequently/frequently. Family environment's deficiencies are obvious and since family environment consists the children's first social environment, it is expected to severely affect the child's drug abuse. According to bibliography both family relations quality and family's formation seem to significantly affect drug abuse from young people (Farrell \& White, 1998). Disorder in family relations with frequently appearing cases of violence, drug abuse, lack of children su- 
pervision and family communication, has been recorded as a significant characteristic of young people and their families who have approached the Special Treatment Programme of "Strofi", by many relevant studies (Koutrouvidis \& Koutras, 2007).

School failure and interruption are quite common in the sampled students, since just $13 \%$ of them hold a High School certificate, while the rest of the students abandoned school before seeking for help in the Special Treatment Programme and placing themselves among the educational process through the Commutative School of "Strofi". The biggest school interruption rates are recorded in classes A and B of the High School, something that indicates high rates of drug abuse at High School. Related studies indicate that drug abuse rates increase with the school class. Drug abuse appears to be significantly increased in High School students rather than Senior School students. The difference between the two school stages suggests that probably the student's transition and accession to High School legalizes different types of behavior and, in essence, allows the young student to accept drug abuse/trial as a harmless act. Students that use drugs can not realize the related risks, while they attribute many more positive points to drug users than negative ones (Apostolaki, 2001). Although drug abuse is very common in High School, High School environment has higher expectations and seems to impede the teenager user, leading him step by step to school abandonment. Similar findings have been noted by relevant research (Koutrouvidis \& Koutras, 2007).

The school failure of the sampled students and teenagers is also depicted in their marginal presence at school. Absence rates are very high due to the need for drug abuse, health problems probably correlated to drug abuse, lack of interest for the Greek school and fear of school failure. Their class presence is not effective, since they are not able to attend it and they are not attracted to the way the lesson is delivered. According to them, school assignments are favouring the bright students and the school environment is quite competitive and not at all friendly. The relations with their professors are characterized by lack of understanding and support to students' problems. The school, as an institution, has failed the students according to the way that they have experienced it. Only $57 \%$ of the students are confident of receiving the Senior/High school certificate and this positive attitude towards education is attributed to their participation in the educational programme of the Commutative School of "Strofi", which supports them and places them among education and society.

Today's school environment and the traditional educational process is not only unattractive to drug abusing students, but it also alienates and marginalizes them. School failure provides a fertile ground for the deterioration of drug abuse. Drug abuse does not allow for sure the young people to place themselves in the educational process. Moreover, the lack of incentives for learning and the lack of interest from the school environment to support the problematic student bare great responsibility for the bad school performance of young drug users. School failure usually leads to school interruption, which is often imposed to the student who displays defaulting behaviour, and consequently stigmatizes him. School abandonment offers nothing positive to the student's life. Away from school, the teenager is getting more and more involved with drug abuse, as confirmed by relative researches (Koutrouvidis \& Koutras, 2007). In conclusion, school failure and interruption lead young drug abusing students to further involvement with drugs.

As a suggestion, today's school and tutors must recognize young peoples' needs and problems, concede the drug abuse phenomenon in the student population and render school as a barrier against drug abuse. Many factors such as educational process, teaching methods and relations between professors and students have to change, in order for school to correspond to the aforementioned role. Today's traditional school has to be replaced by the modern student-focused democratic school.

Student-focused school corresponds to students' needs, does not stigmatize them as good and bad and responds to their opinions within a democratic frame. It operates in a respectful and trustful environment and it embraces students having individual problems such as learning deficiencies, default, drug abuse. Students actively participate in the educational process, they are creative and feel free to express their opinions in the class. Professors and students share trustful and mutual interest relations.

The student-focused school operates with modern team-cooperative teaching methods that make learning much more appealing to the students and attracts them all in the learning process. This way, the school can form an effective educative and social institution. The majority of the students, who participated in the research, commented positively on the team-cooperative teaching methods, as well as, the students' participation in interesting activities. The class lesson attracts much more participation from the students, when it is delivered through interesting teamwork activities. The teacher should use the course-book as a means of preparation for his class, instead of just reproducing its content. The students' active participation through creative tasks related with topics from the school book and topics of their preference reinforces the education process. Modern elec- 
tronic supervisory means make the lesson much more appealing. Even the class desks' arrangement should give the opportunity to class members to communicate, thus, the type " $\Pi$ " is suggested. Physics and computers school laboratories offer to students the opportunity to discover knowledge and they must acquire an active role. Also, outdoor teamwork, cultural and sports activities must be reinforced and they must be placed within the school's daily curriculum, so that students can involve themselves with interesting activities in their free time. The abovementioned student-focused school should ensure students' active participation, make children more active and pleasant and avert drug abuse phenomena. The school is indeed a form of prevention against drug abuse.

The results of the research also indicated that school should definitely operate according to specific rules and discourage deviances. Its role, as far as default problems are concerned, is not just to impose punishments and sentences, far less to abort students. In such cases, the school must treat these problems as social phenomena which concern students and it must seek for solutions in collaboration with students and their parents. When the school opens up to the society, it functions as an institute of prevention. Children facing drug abuse problems, instead of being drawn away from school environment, should find support in it. Psychological support and learning incentives could really help such students. For this purpose, school professors should be continuously educated on topics concerning drug addiction and they should apply prevention programmes in their school, when faced with drug abuse problems.

The student-focused school, which applies the team-cooperative teaching and operates in a democratic and an open-to-society environment, protects its students from drug abuse phenomena. This school must be supported by the state with strong funds and also by constructing new buildings that have the appropriate infrastructure for the modern school to correspond to students' needs.

\section{References}

Andersson, B., Hibell, B., Beck, F., Choquet, M., Kokkevi, A., Fotiou, A., Molinaro, S., Nociar, A., Sieroslawski, J., \& Trapencieris, M. (2007). Alcohol and Drug Use Among European 17-18 Year Old Students. Data from the ESPAD Project, 154, 491-516.

Apostolaki, A. (2001). Drug and Distorted Behaviour. Athens: Ph.D., Law School.

Ausubel, D., Novak, J., \& Hanesian, H. (1978). Educational Psychology: A Cognitive View (2 ${ }^{\text {nd }}$ ed.). New York: Holt, Rinehart \& Winston.

Bertrand, Y. (1994). Comtemporary Educatiocal Theories. Athens: Ellinika Grammata.

Bond, L., Butler, H., Thomas, L., Carlin, J., Glover, S., Bowes, G., \& Patton, G. (2007). Social and School Connectedness in Early Secondary School as Predictors of Late Teenage Substance Use, Mental Health, and Academic Outcomes. Journal of Adolescent Health, 40, 357.e9-e18.

Cochrane, J., Chen, H., Conigrave, K. M., \& Hao, W. (2003). Alcohol Use in China. Alcohol, 38, 537-542. http://dx.doi.org/10.1093/alcalc/agg111

Cooley-Strickland, M., Quille, T. J., Griffin, R. S., Stuart, E. A., Bradshaw, C. P., \& Furr-Holden, D. (2009). Community Violence and Youth: Affect, Behavior, Substance Use, and Academics. Clinical Child and Family Psychology Review, 12, 127-156. http://dx.doi.org/10.1007/s10567-009-0051-6

Duncan, S. C., Strycker, L. A., \& Duncan, T. E. (1999). Exploring Associations in Developmental Trends of Adolescent Substance Use and Risky Sexual Behaviour in a High-Risk Population. Journal of Behavioral Medicine, 22, 21-24. http://dx.doi.org/10.1023/A:1018795417956

EMCDDA (2008). The State of the Drugs Problem in Europe. Luxembourg: EMCDDA.

Faggiano, F., Vigna-Taglianti, F. D., Versino, E., Zambon, A., Borraccino, A., \& Lemma, P. (2008). School-Based Prevention for Illicit Drugs Use: A Systematic Review. Preventive Medicine, 46, 385-396. http://dx.doi.org/10.1016/j.ypmed.2007.11.012

Farrell, A. D., \& White, K. S. (1998). Peer Influences and Drug Use among Urban Adolescents: Family Structure and Parent-Adolescent Relationship as Protective Factors. Journal of Consulting and Clinical Psychology, 66, 248-258. http://dx.doi.org/10.1037/0022-006X.66.2.248

Ferguson, D. M., Boden, J. M., \& Horwood, L. J. (2006). Cannabis Use and Other Illicit Drug Use: Testing the Cannabis Gateway Hypothesis. Addiction, 101, 556-569. http://dx.doi.org/10.1111/j.1360-0443.2005.01322.x

Fletcher, A., Bonell, C., \& Hargreaves, J. (2008). School Effects on Young People’s Drug Use: A Systematic Review of Intervention and Observational Studies. Journal of Adolescent Health, 42, 209-220. http://dx.doi.org/10.1016/j.jadohealth.2007.09.020

Fontana, D. (1996). Psychology for Educators. Athens: Savvalas Editions. 
Galaif, E. R., Sussman, S., Newcomb, M. D., \& Locke, T. F. (2007). Suicidality, Depression, and Alcohol Use among Adolescents: A Review of Empirical Findings. International Journal of Adolescent Medicine and Health, 19, 27-35. http://dx.doi.org/10.1515/IJAMH.2007.19.1.27

Gardner, H. (1993). Frames of Mind: The Theory of Multiple Intelligences. New York: Basic Books.

Hamilton, H. A., Noh, S., \& Adlaf, E. M. (2009). Adolescent Risk Behaviours and Psychological Distress across Immigrant Generations. Canadian Journal of Public Health, 100, 221-225.

Hawkins, J. D., Catalano, R. F., \& Miller, J. Y. (1992). Risk and Protective Factors for Alcohol and Other Drug Problems in Adolescence and Early Adulthood: Implications for Substance Abuse Prevention. Psychological Bulletin, 112, 64-105. http://dx.doi.org/10.1037/0033-2909.112.1.64

Hibell, B., Andersson, B., Bjarnason, T., Ahlström, S., Balakireva, O., Kokkevi, A., \& Morgan, M. (2004). The ESPAD Report 2003. Alcohol and Other Drug Use among Students in 35 Countries. Stockholm: The Swedish Council for Information on Alcohol and Other Drugs.

Kandel, D. B., \& Logan, J. A. (1984). Patterns of Drug Use from Adolescence to Young Adulthood: I. Periods of Risk for Initiation, Continued Use, and Discontinuation. American Journal of Public Health, 74, 660-666. http://dx.doi.org/10.2105/AJPH.74.7.660

Karam, E., Kypri, K., \& Salamoun, M. (2007). Alcohol Use among College Students: An International Perspective. Current Opinion in Psychiatry, 20, 213-221.

KETHEA (2007). Sociodemographic Characteristics and Patterns of Use of Individuals Who Contacted KETHEA's Counselling Centres between 2000 and 2006. Athens.

Kodjo, C. M., \& Klein, J. D. (2002). Prevention and Risk of Adolescent Substance Abuse. The Role of Adolescents, Families, and Communities. Pediatric Clinics of North America, 49, 257-268. http://dx.doi.org/10.1016/S0031-3955(01)00003-7

Kokkevi, A. E., Arapaki, A. A., Richardson, C., Florescu, S., Kuzman, M., \& Stergar, E. (2007). Further Investigation of Psychological and Environmental Correlates of Substance Use in Adolescence in Six European Countries. Drug and Alcohol Dependence, 88, 308-312. http://dx.doi.org/10.1016/j.drugalcdep.2006.10.004

Kokkevi, A., Nic, Gabhainn, S., \& Spyropoulou, M. (2006). Early Initiation of Cannabis Use: A Cross-National European Perspective. Journal of Adolescent Health, 39, 712-719.

Koutrouvidis, P., \& Koutras, V. (2007). The School Course of Adolescent Drug Abusers, School Adjustment, School Failure, Educational Re-Entrance. Exartisis (Scientific Journal on Addiction Issues in Greece), 12, 42-62.

Lynskey, M. T., Heath, A. C., Bucholz, K. K. et al. (2003). Escalation of Drug Use in Early Onset Cannabis Users vs CoTwin Controls. JAMA, 289, 427-433. http://dx.doi.org/10.1001/jama.289.4.427

Lynskey, M., \& Hall, W. (2000). The Effects of Adolescent Cannabis Use on Educational Attainment: A Review. Addiction, 95, 1621-1630. http://dx.doi.org/10.1046/j.1360-0443.2000.951116213.x

Madarasová, G. A., Stewart, R., van Dijk, J. P., Orosová, O., Groothoff, J. W., \& Post, D. (2005). Influence of Socio-Economic Status, Parents and Peers on Smoking Behaviour of Adolescents. European Addiction Research, 11, $204-209$. http://dx.doi.org/10.1159/000086403

Matsaggouras, H. (1987). Team Building and Education. Athens: Glaros.

Melzer-Lange, M. D. (1998). Violence and Associated High-Risk Health Behavior in Adolescents. Substance Abuse, Sexually Transmitted Diseases, and Pregnancy of Adolescents. Pediatric Clinics of North America, 45, 307-317.

http://dx.doi.org/10.1016/S0031-3955(05)70007-9

Meyer, E. (1995). Group Teaching: Examples. Thessaloniki: Kyriakidi.

Miller, J. W., Naimi, T. S., Brewer, R. D., \& Jones, S. E. (2007). Binge Drinking and Associated Health Risk Behaviors among High School Students. Pediatrics, 119, 1035-1036. http://dx.doi.org/10.1542/peds.2007-0468

Parry, C. D., Myers, B., Morojele, N. K., Flisher, A. J., Bhana, A., Donson, H., \& Plüddemann, A. (2004). Trends in Adolescent Alcohol and Other Drug Use: Findings from Three Sentinel Sites in South Africa (1997-2001). Journal of Adolescence, 27, 429-440. http://dx.doi.org/10.1016/j.adolescence.2003.11.013

Peers, I. S. (1996). Statistical Analysis for Education and Psychology. London: Falmer.

Rousea, P., \& Vretakou, B. (2006). Drop-Out Problem in Stage I of the Secondary Education System. Pedagogical Institute, Ministry of National Education and Religion of Greece.

Simons-Morton, B. G., Farhat, T., ter Bogt, T. F., Hublet, A., Kuntsche, E., Nic Gabhainn, S, Godeau, E., \& Kokkevi, A. (2009). HBSC Risk Behaviour Focus Group. Gender Specific Trends in Alcohol Use: Cross-Cultural Comparisons from 1998 to 2006 in 24 Countries and Regions. International Journal of Public Health, 54, 199-208. http://dx.doi.org/10.1007/s00038-009-5411-y 
Stefanis, C. N., \& Kokkeve, A. (1986). Depression and Drug Use. Psychopathology, 19, 124-131. http://dx.doi.org/10.1159/000285143

Townsend, L., Flisher, A. J., \& King, G. (2007). A Systematic Review of the Relationship between High School Dropout and Substance Use. Clinical Child and Family Psychology Review, 10, 295-317.

http://dx.doi.org/10.1007/s10567-007-0023-7

Vygotsky, L. S. (1997). Mind in Society. Athens: Gutenberg.

WHO (1997). Cannabis: A Health Perspective and Research Agenda. Geneva: WHO.

WHO (1999). Global Status Report on Alcohol. Geneva: WHO.

WHO (2001). Tobacco and the Rights of the Child. Geneva: WHO.

Yamaguchi, K., \& Kandel, D. B. (1984). Patterns of Drug Use from Adolescence to Young Adulthood: Predictors of Progression. American Journal of Public Health, 74, 673-681. http://dx.doi.org/10.2105/AJPH.74.7.673

Yu, J., \& Williford, W. R. (1992). The Age of Alcohol Onset and Alcohol, Cigarette, and Marijuana Use Patterns: An Analysis of Drug Use Progression of Young Adults in New York State. The International Journal of the Addictions, 27, 13131323. http://dx.doi.org/10.3109/10826089209047353 


\section{APPENDIX}

\section{QUESTIONAIRIES}

\section{Questionnaire}

Dear student,

This questionnaire asks for information about you, your interests and your opinion about Greek School. If you don't attend any school you should complete the questionnaire according to your last attended school. Answering this questionnaire should require no more than 15 minutes. To make it as easy as possible for you to respond, most questions may be answered simply by clicking in the appropriate box. All responses are anonymised and treated in the strictest confidence;

Please note that your participation is entirely voluntary. However, I urge you to answer all the questions since your input is necessary to strengthen the validity and consequent impact of the findings.

Thank you very much for the time and effort you put in responding to this questionnaire.

Complete the class you attend now. High school........ College........ School of Strofi.

If you have completed School of Strofi completed it here.

If you have abandoned School report the year and the class.

1. What is your gender? Female $\quad \square \quad$ male

2. Age in years

3. Where do you live: Town:

Suburb:

Village:................. State:.....

4. Where did you born;

5. Place of father birth;

6. Place of mother birth;

7. How many years do you live in Greece
0 - 1
$1-2$
$2-3$
$3-4$
$4-5$
$5+$

8. Before moving to Greece, your ex-country;

9. Father occupation; (now)

$9 \alpha$. Father unemployed? (tick)

10. Mother occupation; (now)

$10 \alpha$. Mother unemployed? (tick)

11. What is the highest degree or level of school your father has completed? If currently enrolled, highest degree received.

- school to $8^{\text {th }}$ grade

- Some high school, no diploma

- High school graduate, diploma or the equivalent (for example: GED)

- Some college credit, no degree

- Trade/technical/vocational training

- Associate degree

- Bachelor's degree

- Master's degree

- Professional degree 
- Doctorate degree

12. What is the highest degree or level of school your father has completed? If currently enrolled, highest degree received - school to $8^{\text {th }}$ grade

- Some high school, no diploma

- High school graduate, diploma or the equivalent (for example: GED)

- Some college credit, no degree

- Trade/technical/vocational training

- Associate degree

- Bachelor's degree

- Master’s degree

- Professional degree

- Doctorate degree

13. Did you attend preschool education; If yes, for how long; (tick)
Not at all
Few months
1 year
2 years

14. With whom do you live?

Father.

Mother

Brother/Mother

Grandfather/Grandmother.

Uncles.

Other people...

15. Your grade in school;

(Tick)

16. How often did you feel despert with;

Lessons
Exams
Eery often Often Rare time to time Fer
Other students
Teachers
Parents

17. How ofted did you were absent in school; (tick)

$\begin{array}{lcccc}\text { Very often } & \text { Often } & \text { From time to time } & \text { Rare } & \text { Never } \\ (5-6 \text { times } & (2-3 \text { times } & \text { (Once } & (1-2 \text { times } & \\ \text { per week }) & \text { per week }) & \text { per week }) & \text { per month })\end{array}$

18. If you were absent report the reason; (Place your option with priority):

- Feeling sick.

- Feeling bored

- Fear for a lesson. 
- You couldn’t understand teachers.

- Your parents asked all the times for work.

- You didn’t enjoy Greek school.

- Not eating/not sleeping well.

- Fear for not doing your homework.

- preferring to do other things.

19. Do you know that studying High school is obligatory;

Yes No

20. When attending school, your best friend were;

- Regional Greek.

- Your fellow residents

- Students from other countries.

21. Did you face problem in participating in the lesson for some of the following reasons; (tick)

- language and communication problems.

- attention disorder.

- 'boring' lecture.

- other reason.

- everything was OK.

22. Did your parents asked you to stay at home in order to help them;

If yes, please describe;

- house cleaning.....

- growing up children

- job.

- something else.

23.Report some reasons why children abandon school; (Write 2-3 lines).

24. are you planning to graduate; (tick)

Absolutely yes Absolutely no Not sure

25. Which language did you spoke in school with your friends;

Greek $\quad \square \quad$ your native language $\quad \square \quad$ both languages

26. Which language did you spoke at home;

Greek $\quad \square$ your native language $\quad \square \quad$ both languages

27. How fluent do you speak Greek;

Understand Greek 


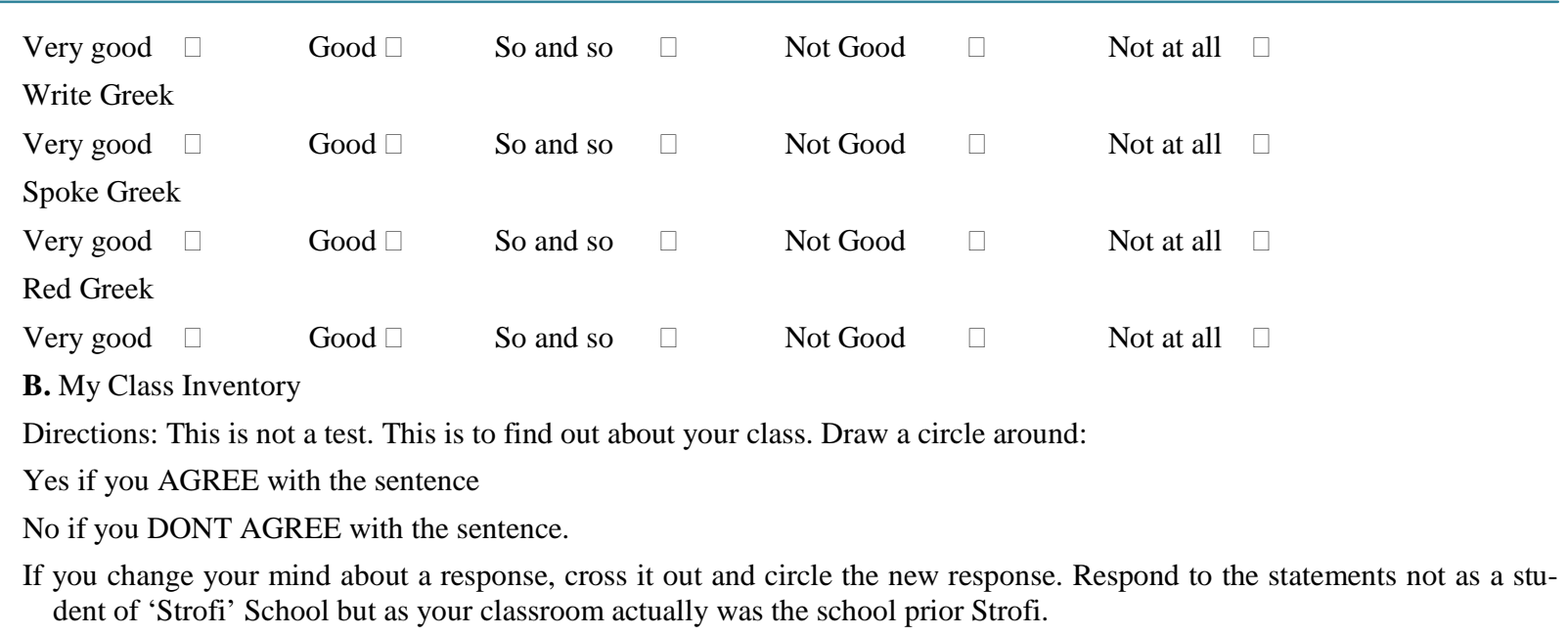

1. Students enjoy their schoolwork in my class.

Yes No

2. Students are always fighting with each other.

Yes No

3. Students often race to see who can finish first.

Yes No

4. In our class the work is hard to do

Yes No

5. In my class everyone is my friend.

Yes No

6. Some students are not happy in class

Yes No

7. Some of the students in our class are mean

Yes No

8. Most students want their work to be better than their friends work

Yes No

9. Most students can do their schoolwork without help..

Yes

No

10. Some people in my class are not my friends.

Yes No

11. Students seem to like the class.

Yes No

12. Many students in our class like to fight.

Yes No

13. Some students feel bad when they don't do as well as the others.

Yes No

14. Only the smarter students can do their work.

Yes

No

15. All students in my class are close friends.

Yes No

16. Some of the students do not like the class.

Yes

No

17. Certain students always want to have their way. 
Yes

No

18. Some students always try to do their work better than the others

Yes

No

19. Schoolwork is hard to do.

Yes No

20. All of the students in my class like each other.

Yes

No

21. This class is fun.

Yes

No

22. Students in our class fight a lot.

Yes

No

23. A few students in my class want to be first all the time

Yes No

24. Most of the students in my class know how to do their work.

Yes

No

25. Students in our class like each other as friends

Yes

No

\section{Questionnaire}

Dear student,

we have created this questionnaire in order to know how you would like the school today. That is how you prefer the lesson in class, what relationship would like to have with your teachers and classmates, etc.

Instructions: Choose the correct answer A or B, depending on the answer you agree the most. Thank you for your participation.

1. As far as lesson delivery, would you prefer to take place through dialogue and all the students to be able to express their opinion?
A. Yes
B. No

2. During the lesson in the class, would you prefer to watch the teacher's lecture without saying your opinion?

A. Yes

B. No

3. Do you consider important for the class lesson to be interesting for the students and to help them face their needs and problems?
A. Yes
B. No

4. It seems to me more interesting to participate in group activities. For example I would prefer to draw a cell in biology or do an experiment in physics, rather than watching the professor lecturing.

\section{A. I Agree \\ B. I Disagree}

5. Do you think it would be interesting, not only the teacher, but every student to be able to propose topics for discussion in the classroom?
A. Yes
B. No

6. Would you like, as a student, to be able to propose a different topic for discussion in the classroom, which is not relative to the school book topics, for example, something that concerns many young people.

A. Yes

B. No

7. When the teacher proposes topics for a home work, I would prefer, in most cases, to work with my other classmates as a 
group rather than individually, because that way we will all learn to work together and to respect the one another.
A. I agree
B. I disagree

8. Would you like to participate in outdoor group activities, such as sports, students' newspaper and theatrical performance?

A. Yes

B. No

9. Would you like to participate in activities, such as visiting scientific and cultural places outside school?
A. No
B. Yes

10. How you prefer the way the school books are written?

A. I prefer the school books like they are written now, for example biology, physics, literature etc.

B. I'd rather there are also books that describe concepts using many sciences. For example, it would be interesting if a school book explains the importance of the water in physics, biology and literature.

11. Besides the lesson in the classroom, there are also programmes such as "Work Project", in which students choose a topic, for example the use of alcohol, separate in groups, search information about it, visit relevant places and prepare a project which they present, supported by their professor. Would you like to participate in that programme?
A. Yes
B. No

12. Programmes of "Environmental Education" is an example of a "Work Project" in greek schools, in which students choose a environmental topic, for example a forest fire, separate in groups, search information about it, visit forests, interviews by experts and prepare a project which they present. Would you like to participate in that programme?
A. Yes
B. No

13. Which way of class desks arrangement do you prefer?

A. I prefer the parallel lines formation, so that each student to watch the teacher, as shown in the figure below.

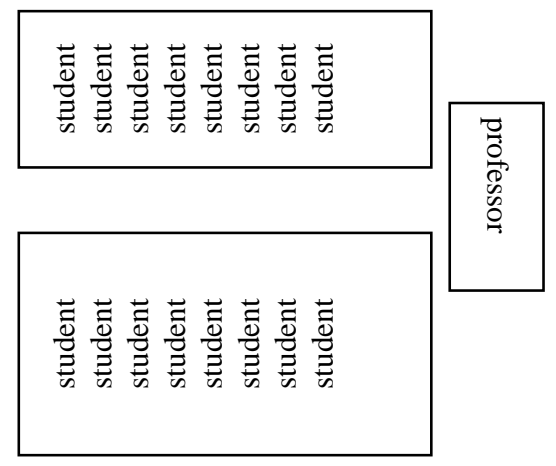

B. I prefer the " $\Pi$ " form, so that everyone, teachers and students to communicate with everyone, as shown in the figure below.

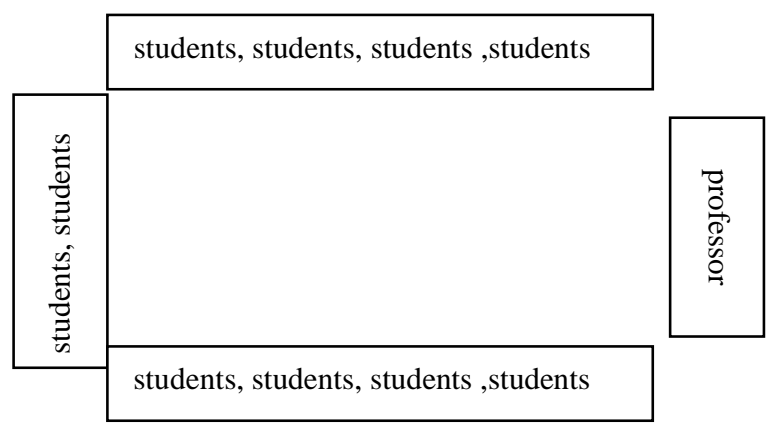

14. Do you think it would be interesting for the class lesson the use of electronics? 
A. Yes, when the computer is only used by the teacher.

B. Yes, when the computer is used mainly by the students.

15.Do you consider important the lesson in school laboratories, such as physics and drawing?

A. Yes, when the school laboratories are only used by the teacher.

B. Yes, when the school laboratories are used mainly by the students.

16. What do you think is the main role of the professor in school?

A. Professors must deliver the book's content and rate students with good or bad degrees.

B. Professors must mainly focus in offering advice and support to students' problems.

17. How do you prefer the teacher in school?

A. Democratic, to respect and to discuss with students.

B. Despotic, to demand the students to obey.

18. Do you think that the professor should give emphasis to the sex characteristics of the individual, such as age, sex, relations with others and emotional state?

A. Yes

B. No

19. Which of the following would fit you as a student?

A. To obey the rules in school and not be very active.

B. To respect the rules in school, to feel free and to be active.

20. What type of student would you like to be?

A. To study my lessons and to obey to my teachers.

B. To be creative, to propose topics for discussion and to have imagination.

21. How do you think should be the students in school?

A. To respect to the otherness and communicate with all.

B. Not to trust different persons and communicate only with persons that share the same interests.

22. How would you like the environment in the classroom?

A. Despotic, students must always obey to the professor.

B. Democratic, students must have freedom of opinion and there must be a mutual respect between professors and students.

23. Who do you think should decide on the rules that set the lessons' delivery?

A. The professors should decide on the rules that set the lessons' delivery and the students must accept these rules without any objection.

B. The professors together with the student should decide on the rules that set the lessons' delivery and they must all respect these rules.

24. How would you like the environment in the school today?

A. Democratic school environment, based on discussion and mutual respect between professors and students.

B. Not democratic school environment, which demand students and professors to abbey to despotic rules and rigid punishments.

25. What do you think should be the role of school today?

A. To teach students to love knowledge, to think, to be active and to be able to solve their problems.

B. To teach students to study and learn the school books.

26.In which school you would prefer to be a student?

A. At that school, where teachers have the power and the students obey.

B. At that school, where teachers and students work together with respect and trust.

27. What relationship would you like to have as a student with your teacher?

A. I would like to have trustworthy relations with my professors both inside as well outside the classroom.

B. I would like to have typical relations with my professors inside the classroom and not many relations outside the classroom.

28. What do you think the teacher should do when a student is aggressive in the classroom? 
A. The teacher should devote significant time to the student and discuss with him.

B. The teacher must behave very strictly to the student and give rigid punishment.

29. What do you think the teacher should do when a student lacks of interest for the lesson?

A. The teacher should punish the student with bad degrees.

B. The teacher should make his lesson more interesting, in terms to increase student's interest.

30. When teachers and students or students quarrel with each other, how do you think the differences should be resolved?

A. Both students and professors should discuss the problems with mutual respect, so finally they all realize that they must respect the school rules. B. The students should be punished strictly, so everyone faithfully obey the rules of the school.

31. How do you think the school should treat the students who are aggressive or take drugs?

A. The school should strictly punish these students, even interrupt their study in case they keep on the same behavior.

B. The school should discuss these problems with both professors, students and parents, and all together must provide solutions. The personal punishment not solves any school problem.

32. What aspect of the following do you agree?

A. The school is an independent place and do not need to support any relationship with the family and the society.

B. The school needs to cultivate strong relations with the family and the society.

33. Write a few word or sentences for the school you would like to be student. 